\title{
Synthesis And Spectroscopic Studying of New Azo Ligand From 2-Naphthol Derivative And It's Complexes With Some Transition Metal Ions
}

Received : 7/12/2017

Hawraa M.alabidi ${ }^{(1)}$
Accepted : 18/1/2018

Ali M.alabidi ${ }^{(2)} \quad$ NahlahF Makki $^{(1)}$

(1)Department of Chemistry ,College of Science ,University of Kufa.

(2) Teacher in the general directorate of education in Al-Najaf Al-Ashraf

E.Mail: hawraam.alabidi@uokufa.edu.iq

\begin{abstract}
:
This work deals with the preparation and identification of new azo ligand as A derivative of 2- Naphthol and It's Complexes with $\mathrm{Co}(\mathrm{II}), \mathrm{Ni}(\mathrm{II}), \mathrm{Cu}(\mathrm{II})$ and $\mathrm{Ag}(\mathrm{I})$ ions. The characterization of this ligand was done ${ }^{1} \mathrm{H}-$ $\mathrm{NMR},{ }^{13} \mathrm{C}-\mathrm{NMR}, \mathrm{Uv}$-Vis and FTIR spectra .The complexes preparation were performed after fixing the optimum conditions of $\mathrm{pH}$ and molar concentration using Uv-Vis spectra of mixed solutions of the above ions with azo ligand .A wide range of $\mathrm{pH}$ and molar concentration obeyed lambert-Beers Law were studies, and the stability constant has been founded at optimum conditions of $\mathrm{pH}$, mole ratio for all complex. Spectrophotometric studies such as IR and Uv-Vis and the molar conductivity of these complexes were used to determine the molecular formulas of the ligand and complexes.

Keyward:Azo compounds ,Complexes , spectrophotometric studying.
\end{abstract}

\section{Introduction :}

Azo compounds have a great importance in a different fields of chemical analysis due to their containment more than one effective group able to form coordination complexes with a various metal ions, which are characterized by their colors, high molar absorption and high stability [1],[2],[3] .

Many researchers have been interested in preparing these types of compounds and studying their properties and effectiveness [4],[5],[6] , especially the difference between the aromatic rings attached to the nitrogen atoms of azo group ,that may be acidic group or basic or both
[7] ,and the distribution of the compensated groups at different sites in the aromatic ring relative to the group of azo, for example, hydroxyl group if attached at the ortho site that make up more importance due to share coordinated with metal ions to form Five chelating ring called This type of compounds are orthohydroxyazo [8]. In this study we are synthesis of new azo ligand, This type of reagent was selected to contain multiple consistency sites and four new chelates complexes with some metallic ions, and to characterization the ligand and Its complexes by using different techniques. 


\section{Materials and Methods:}

All chemicals were from Fluka ,and B.D.H with high purity .Melting points of ligand and it's complexes were determined on a Stuart capillary point apparatus. ${ }^{1} \mathrm{H}-\mathrm{NMR}$ and ${ }^{13} \mathrm{C}$ NMR of ligand recorded by using Burker Ultra

Sheild $(100 \mathrm{MHz})$

Synthesis of azo ligand (2-hydroxy-5-((2hydroxynaphthalen-1-yl) diazenyl)

benzoic acid) :-

The azo ligand ( 2-hydroxy-5-((2hydroxynaphthalen-1-yl) diazenyl) benzoic acid scheme (1), was prepared by dissolving the amine ( 5 -amino salicylic acid) $(0.01 \mathrm{~mol})$ in mixture of $3 \mathrm{ml} \mathrm{HCI}$ Conc. and $25 \mathrm{ml}$ absolute ethanol and stirred for (15) min.in ice bath then ice cold
Electronic spectra in ethanol were recorded by Shimdzu 1800 double beam Spectrophotometer, FTIR spectra recorded on Shimadzu 8400s with $\mathrm{KBr}$ disk. $\mathrm{pH}$ measurements done by using HANNA $\mathrm{pH}$ meter model HI 9321.

solution of $\mathrm{NaNO}_{2}(10 \%) 25 \mathrm{ml}$ was add drop wise on a period of (30) $\min$, the solution become a brown , then add drop wise to another ice cooled solution of 2naphthole $(0.01 \mathrm{~mole})$ in $25 \mathrm{ml}$ of alkaline ethanol, with continuous stirring at $0-5^{\circ} \mathrm{C}$, and left over night. The mixture was natural with dilute hydrochloric acid and ammonia solution until $(\mathrm{pH}=7)$. The solid product was filtered, washed with cold distilled water ,and dried.
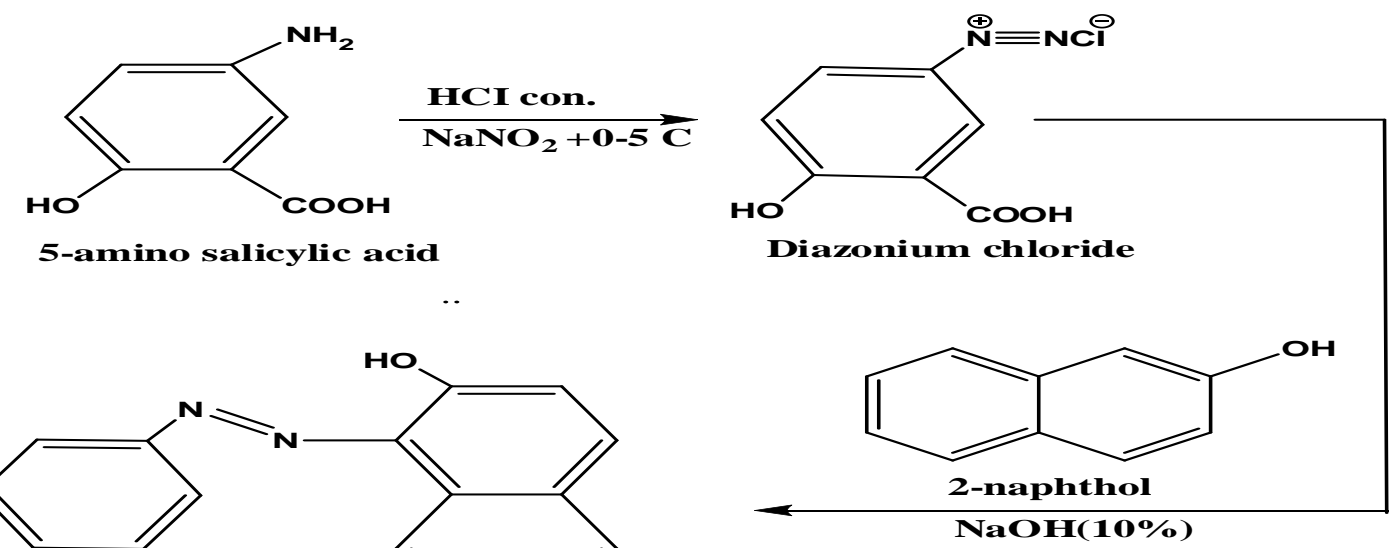

Scheme 1:Preparation of the azo ligand

Synthesis of Metal Complexes : 
The metal complexes were prepared by dissolving ( $2 \mathrm{mmol}$ ) from ligand in $25 \mathrm{ml}$ ethanol and drop-wise with stirring to a stoiciometric amounts of (1:2) ( metal : ligand ) molar ratio of $\mathrm{Cu}$ (II), $\mathrm{Co}$ (II) and $\mathrm{Ni}$ (II) chloride and (1:1) ratio of $\mathrm{Ag}$ (I) nitrate salts , dissolving in $20 \mathrm{ml}$ hot distilled water , the $\mathrm{pH}$ of the reaction mixture was adjusted at optimum $\mathrm{pH}$ for complex . The resulting mixture solution was stirred under reflux for $2 \mathrm{~h}$

. The solid product of the complex was flittered , washed with distilled water, recrystallized from absolute ethanol, and dried at $50{ }^{\circ} \mathrm{C}$ over night. The general reaction for the preparation of the metal complexes of azo ligand is shown below:

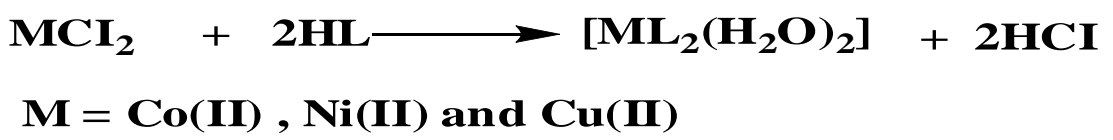

Table (1):Physical Data and Conductivity measurement of azo ligand and its complexes

\begin{tabular}{|c|c|c|c|c|c|}
\hline Compound & M.wt & m.p ${ }^{\circ} \mathrm{C}$ & Color & Yields(\%) & $\begin{array}{l}\text { Conductivity } \\
\text { S.mol }^{-1} \cdot \mathrm{cm}^{2}\end{array}$ \\
\hline Azo ligand & 308 & $248-250$ & Orange & 72 & --- \\
\hline$\left[\mathrm{CoL}_{2}\left(\mathrm{H}_{2} \mathrm{O}\right)_{2}\right]$ & 708.9 & $242-244$ & Brown & 67 & 10.67 \\
\hline$\left[\mathrm{NiL}_{2}\left(\mathrm{H}_{2} \mathrm{O}\right)_{2}\right]$ & 708.6 & $232-234$ & Brown & 70 & 10.86 \\
\hline$\left[\mathrm{CuL}_{2}\left(\mathrm{H}_{2} \mathrm{O}\right)_{2}\right]$ & 713.5 & $243-245$ & Red & 68 & 12.53 \\
\hline$\left[\mathrm{AgL}\left(\mathrm{H}_{2} \mathrm{O}\right)_{2}\right]$ & 450.8 & $>300$ & Red & 72 & 11.23 \\
\hline
\end{tabular}

\section{Results and discussion:}

(1)Electronic spectra: Electronic spectra of ligand show two absorption bands in Uv. region $(198-216) \mathrm{nm}$ due to $\pi-\pi^{*}$ transitions of aromatic rings this band appeared also approximately in the same potions in complexes spectra .Another band at (466) $\mathrm{nm}$ assigned to $n-\pi^{*}$ transitions [9],[10] in Vis. region which is shifted to high wave lengths in complexes spectra as a result of charge transfer transition, showed in Fig.(1-3) and table (2).

\section{(a)-Optimal Concentration for formation of the complexes :}

The optimal Standard calibration curve of $\mathrm{Cu}$ (II), $\mathrm{Co}(\mathrm{II}), \mathrm{Ni}(\mathrm{II})$ and $\mathrm{Ag}(\mathrm{I})$ with azo ligand was plotted in the concentration range $\left(1 \times 10^{-5}\right.$ $\left.1 \times 10^{-4}\right) \mathrm{M}$. concentration of both ligand and metal ions has been selected and the extent of their obedience to the Lambert-Beers Law has been shown to be $\left(1 \times 10^{-4}\right) \mathrm{M}$ the best concentration for the preparation of ligand blending solutions and metal ions under study. The Fig. (4) show the linear relationship of the calibration curve of the concentrations of the mixtures of these ions with the ligand at the wavelength of maximum absorption $\left(\lambda_{\max }\right)$ for $\mathrm{Cu}$ (II) metal ion.

(b) Optimal $\mathrm{pH}$ for formation of the complexes:

Suitable $\mathrm{pH}$ values for metal complex solutions were found to be in the range of $(5-10)$. To evaluate the optimal $\mathrm{pH}$ values of metal complex solutions by using buffer solution of ammonium acetate .The preparation of the complexes has been conducted after fixing the optimum conditions of concentration which obey Lambert-Beers Law these concentration were $\left(1 \times 10^{-5}-1 \times 10^{-4}\right) \mathrm{M}$. The effect of $\mathrm{pH}$ on the absorbance were studied, and the results are shown in Figs. 5 and 6.

\section{(c)Metal: ligand ratios:}

The metal : ligand ratio (M:L)of complexes were determined by the molar ratio method at the wavelength of maximum absorption $\left(\lambda_{\max }\right)$ and fixed $\mathrm{pH}$ and concentrations. The results are summarized in table ( 2 ). The ligand was 
found to form (1:2) chelates with $\mathrm{Co}(\mathrm{II}), \mathrm{Cu}(\mathrm{II})$ and $\mathrm{Ni}(\mathrm{II})$ metal ions and (1:1) chelate with $\operatorname{Ag}(\mathrm{I})$ ion, as shown in Figs. (5-6). The results are in agreement with the values reported for some 2naphthol azo complexes [11].

(d)Determination of Stability Constant of the Metal Complexes:

Stability constants are obtained by measuring the absorbance of solutions of ligand and metal ion mixture at fixed $\lambda_{\max }$ and $\mathrm{pH}$ values. The degree of formation of the complexes are obtained from the relation , $\beta=(1-\alpha) /\left(4 \alpha^{3} c^{2}\right)$ for 1:2 metal complexes,$\beta=(1-\alpha) /\left(\alpha^{2} c\right)$ for $1: 1$ metal chelates and $\alpha=\mathrm{Am}-\mathrm{As} / \mathrm{Am}$. Where Am and As are the absorbance's of the fully and partially formed complex respectively at optimum condition. The calculated $(\log \beta)$ values for each complex are given in Table ( 2 ).The reaction was completed at room temperature and remains stable for long time, This indicates the strong coordination and high stability of the ligand with the metal ions $\mathrm{Co}(\mathrm{II}), \quad \mathrm{Ni}(\mathrm{II}), \mathrm{Cu}(\mathrm{II}) \quad$ and $\quad \mathrm{Ag}(\mathrm{I})$.

Table (2) :Optimum condition and stability constant $\beta$ values of $\mathrm{Co}(\mathrm{II}), \mathrm{Ni}(\mathrm{II})$, $\mathrm{Cu}(\mathrm{II})$ and $\mathrm{Ag}(\mathrm{I})$ complexes.

\begin{tabular}{|c|c|c|c|c|c|c|}
\hline Compound & $\begin{array}{c}\text { Berr's law } \\
\text { range }\end{array}$ & $\mathrm{pH}$ & $\lambda_{\max }$ & Metal:Ligand & $\mathrm{B}$ & $\log \beta$ \\
\hline$\left[\mathrm{CoL}_{2}\left(\mathrm{H}_{2} \mathrm{O}\right)_{2}\right]$ & $0.1-1 \times 10^{-4}$ & 7 & 504 & $1: 2$ & $2.4 \times 10^{11}$ & 11.38 \\
\hline$\left[\mathrm{NiL}_{2}\left(\mathrm{H}_{2} \mathrm{O}\right)_{2}\right]$ & $0.1-1 \times 10^{-4}$ & 8 & 510 & $1: 2$ & $1.6 \times 10^{11}$ & 11.2 \\
\hline$\left[\mathrm{CuL}_{2}\left(\mathrm{H}_{2} \mathrm{O}\right)_{2}\right]$ & $0.1-1 \times 10^{-4}$ & 6 & 562 & $1: 2$ & $4 \times 10^{11}$ & 11.6 \\
\hline$\left[\mathrm{AgL}\left(\mathrm{H}_{2} \mathrm{O}\right)_{2}\right]$ & $0.1-1 \times 10^{-4}$ & 6 & 508 & $1: 1$ & $3.1 \times 10^{9}$ & 9.49 \\
\hline
\end{tabular}

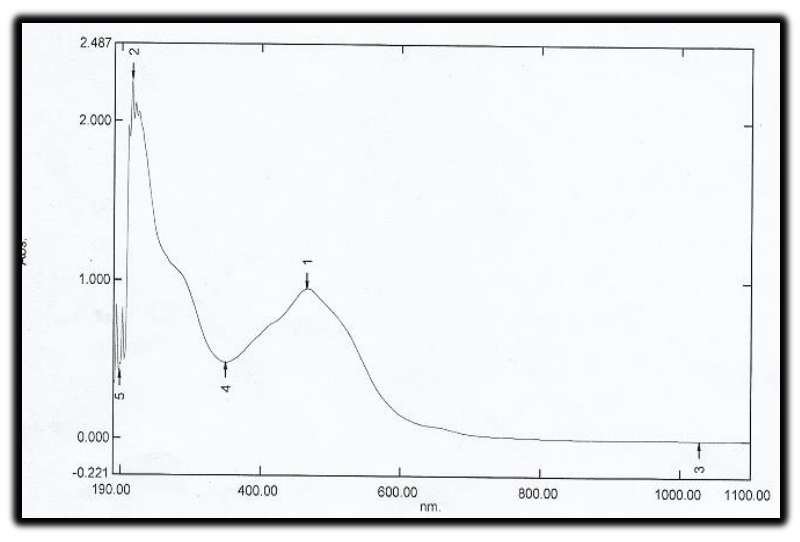

Fig(1):Electronic spectra of azo ligand.

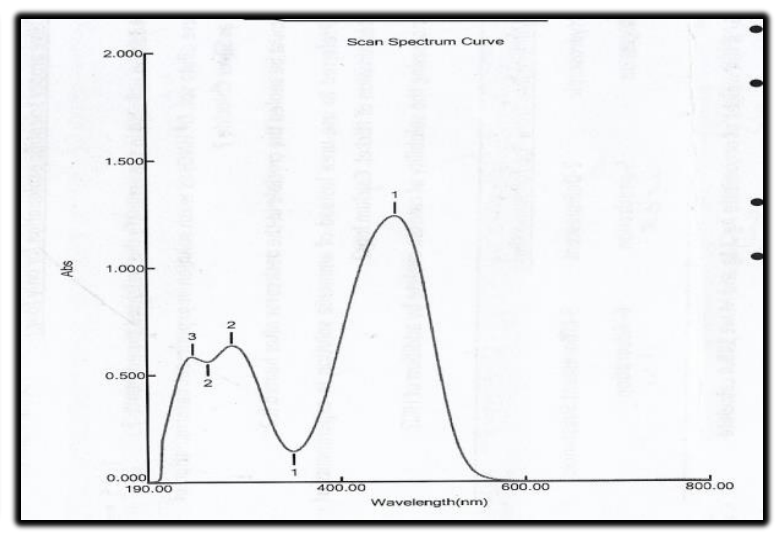

Fig(2): Electronic spectra of $\mathrm{Ni}(\mathrm{II})$ complex 


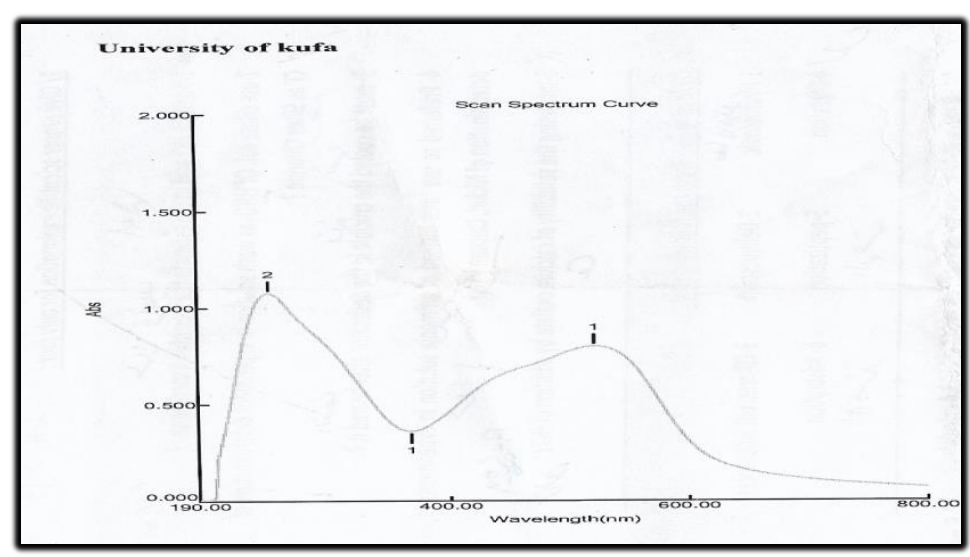

Fig(3):Electronic spectra of $\mathrm{Cu}(\mathrm{II})$.

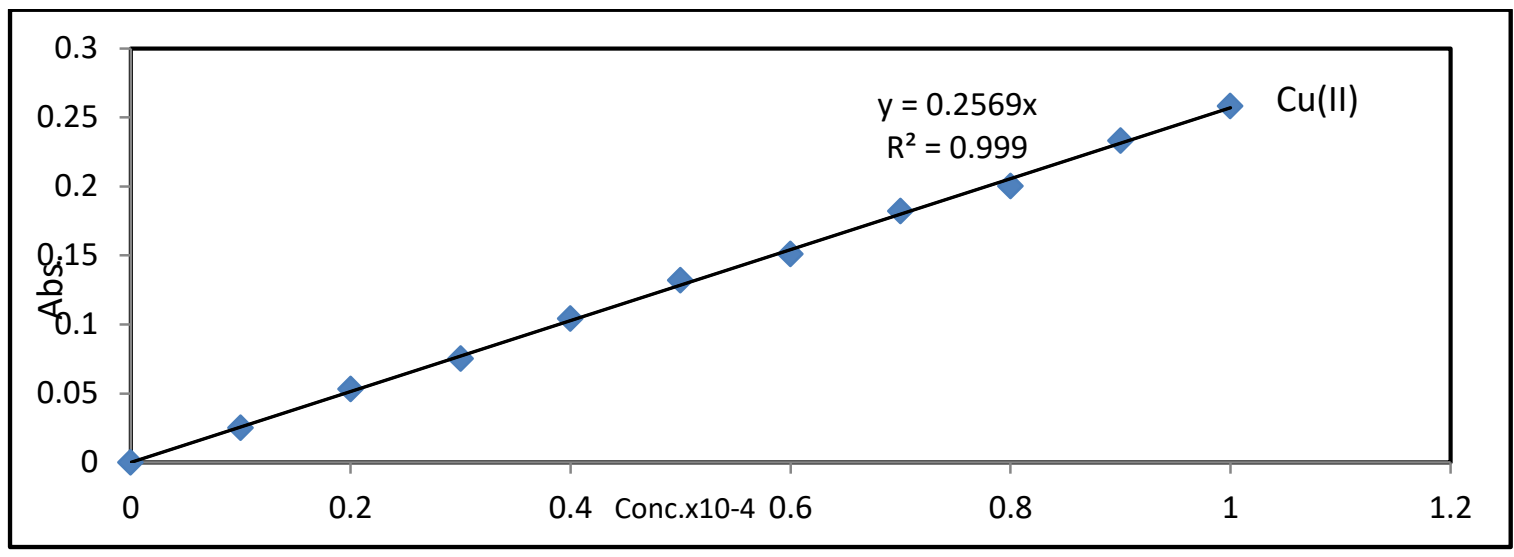

Fig(4):Calibration curve of $\mathrm{Cu}(\mathrm{II})$ complex.
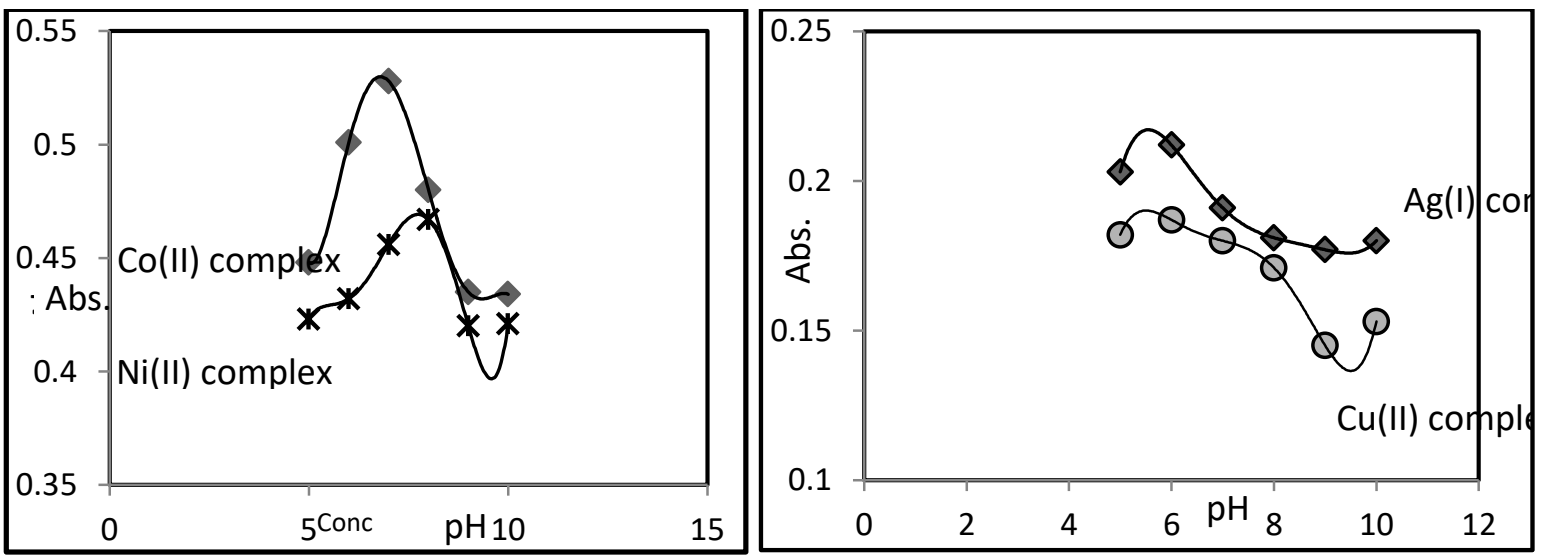

Fig.(5):pH effect of $\mathrm{Co}(\mathrm{II})$ and $\mathrm{Ni}(\mathrm{II})$ complexes. Fig.(6):pH effect of $\mathrm{Cu}(\mathrm{II})$ and $\mathrm{Ag}(\mathrm{I})$ complexes

(2) Infrared spectra of the azo ligand and it's complexes :

The infrared spectral data is shown in table (3) the assignment of infrared bands the azo ligand and it's complexes with $\mathrm{Co}(\mathrm{II}), \mathrm{Ni}(\mathrm{II}), \mathrm{Cu}(\mathrm{II})$ and $\mathrm{Ag}(\mathrm{I})$ ions are in agreement with expectation Figures (7-10
). The broad band at (3419 cm-1) in the spectrum of free azo ligand Fig.(7) which assigned to $v(-\mathrm{OH})$ stretching [12].This band suffers little displacement because of the coordinate with the metal ions and also 
the presence of $-\mathrm{OH}$ group in the 5-amino salicylic acid .

The spectrum of the ligand shows sharp absorption band at $1666 \mathrm{~cm}-1$ due to $v(\mathrm{C}=\mathrm{O})$ of carboxylic group ,It is observed with a little

The bands of $v(\mathrm{~N}=\mathrm{N})$ group appeared in (1489) and (1444) $\mathrm{cm}-1$ in ligand spectrum shifted to a lower frequencies in complexes spectra that indicated the azo group coordinated with metal [14].

New weak bands in the region $472-432 \mathrm{~cm}^{-1}$ and $528-538 \mathrm{~cm}-1$ were observed in the spectra change in shape and shifted to higher frequencies 1676-1670 cm-1 in the prepared complexes spectra. These differences suggest hydrogen bonding between $\mathrm{C}=\mathrm{O}$ of carboxylic group and $\mathrm{OH}$ group ortho to it [13].

of metal complexes due to $v(\mathrm{M}-\mathrm{N})$ and $v(\mathrm{M}-\mathrm{O})$ respectively. [15]

Therefore,the IR spectra indicate that the ligand behaves as monobasic acid and the coordination sites - $\mathrm{OH}$ group of naphthol ring and azo group of the ligand .

Table (3): Characteristic IR absorption bands of the ligand and it's complexes in $\mathbf{~ m}^{-1}$ units.

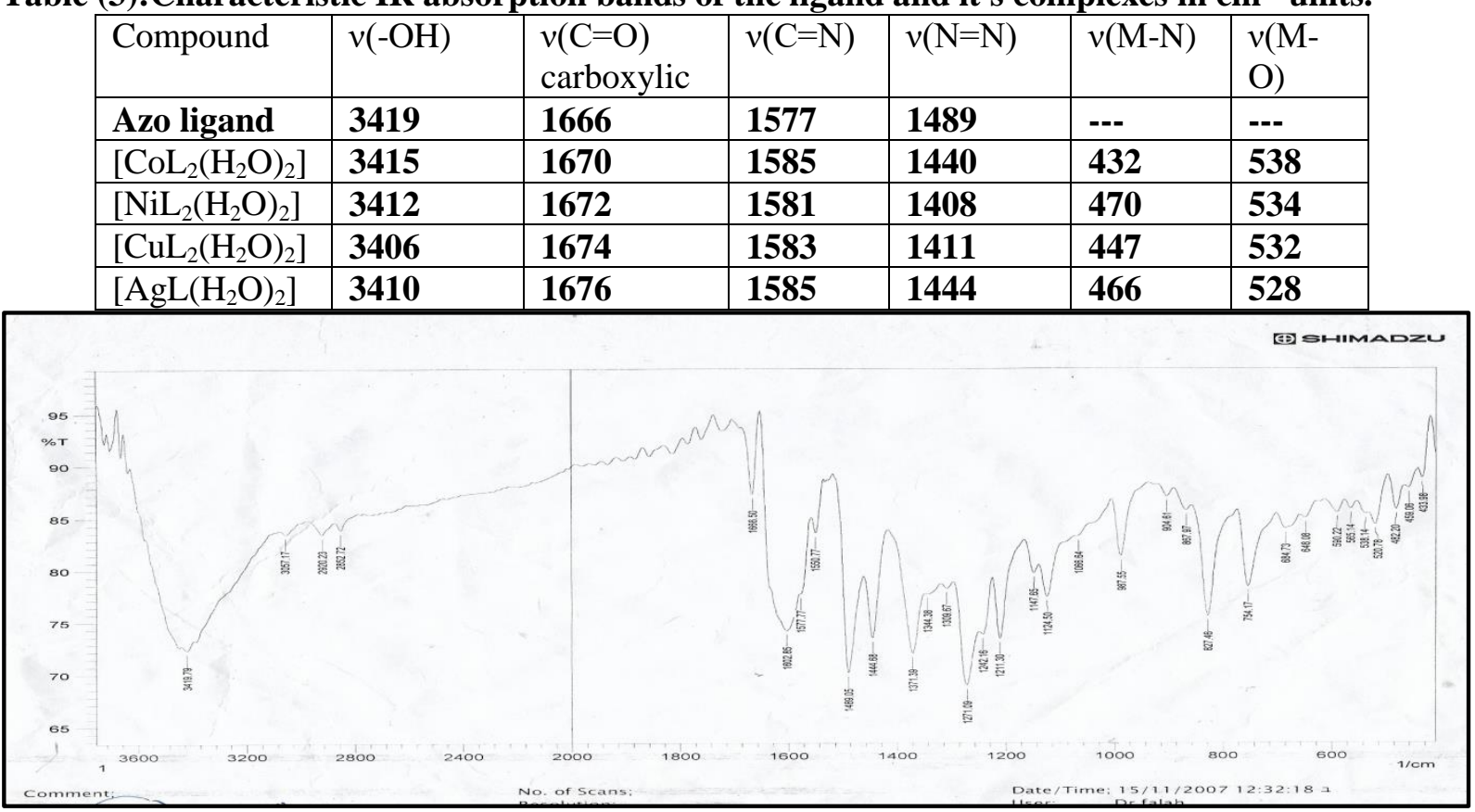

Fig.(7):FTIR spectra of azo ligand

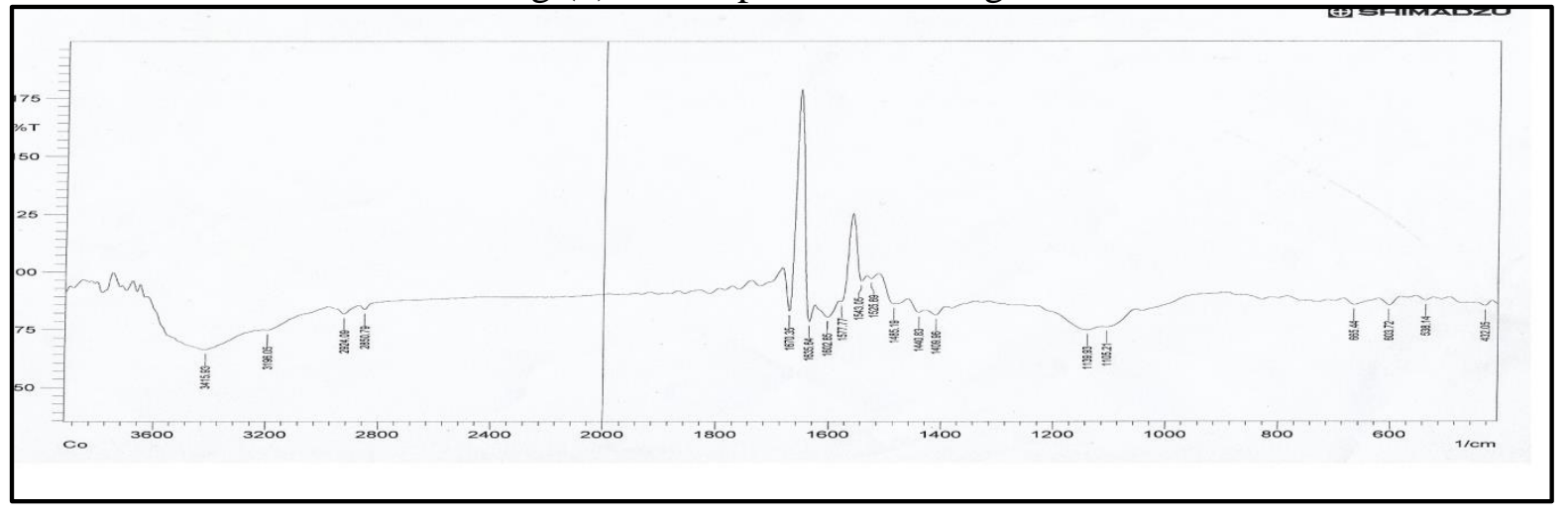

Fig.(8):FTIR spectra of Co(II) complex. 


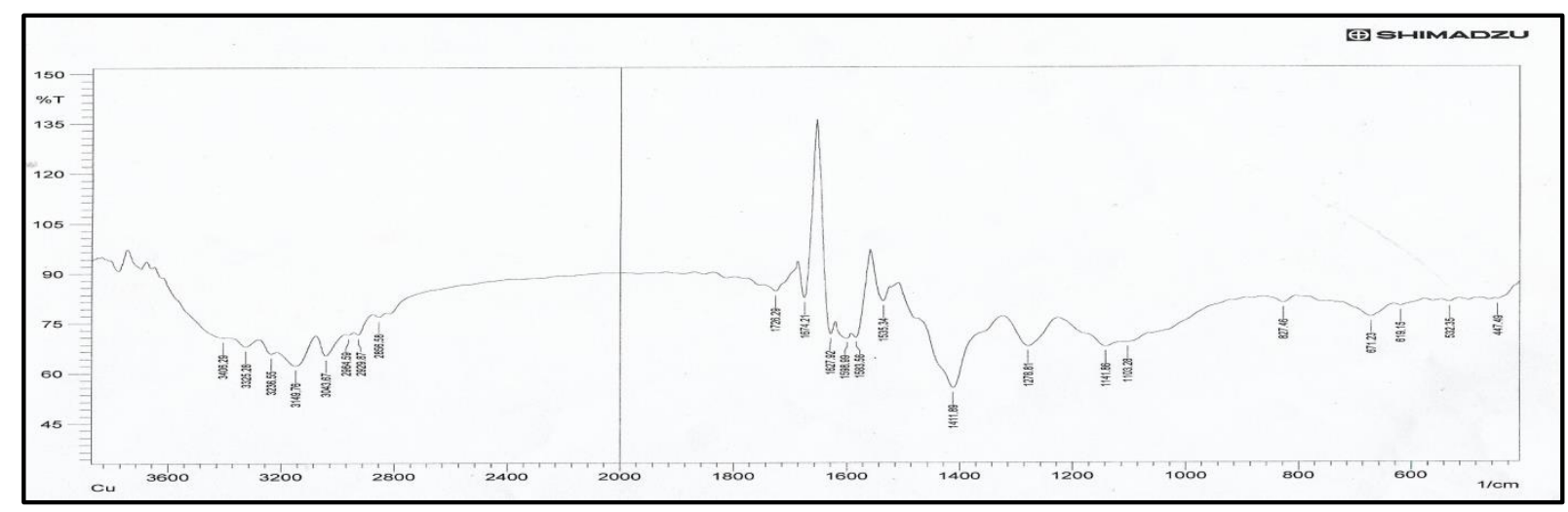

Fig.(9):FTIR spectra of $\mathrm{Cu}(\mathrm{II})$ complex.

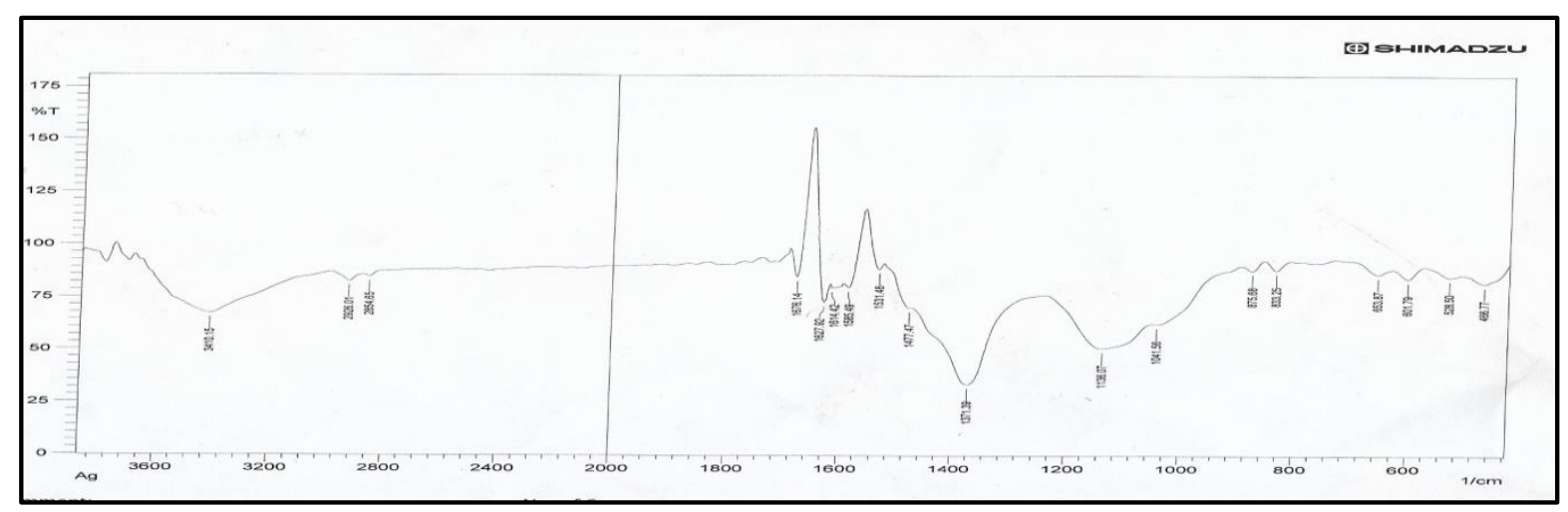

Fig.(10):FTIR spectra of $\mathrm{Ag}(\mathrm{I})$ complex

\section{3- ${ }^{1} \mathrm{H}-\mathrm{NMR}$ and ${ }^{13} \mathrm{C}$-NMR Spectra :}

$\mathrm{OH})$ may be interacted with signals of

${ }^{1} \mathrm{H}-\mathrm{NMR}$ and ${ }^{13} \mathrm{C}-\mathrm{NMR}$ spectra for ligand in DMSO showed in Fig. (11 and 12). A singlet peak was appeared at $\delta(15) \mathrm{ppm}$ in the H-NMR spectra for ligand which was due to one proton of free carboxylic acid moiety in salicylic acid ring [16]. The multiple signals noted in the region $\delta$ (8.85- 6.8) $\mathrm{ppm}$ for ligand, these were referred to aromatic proton in benzene ring. Proton signal of hydroxyl group (aromatic proton in benzene ring. 


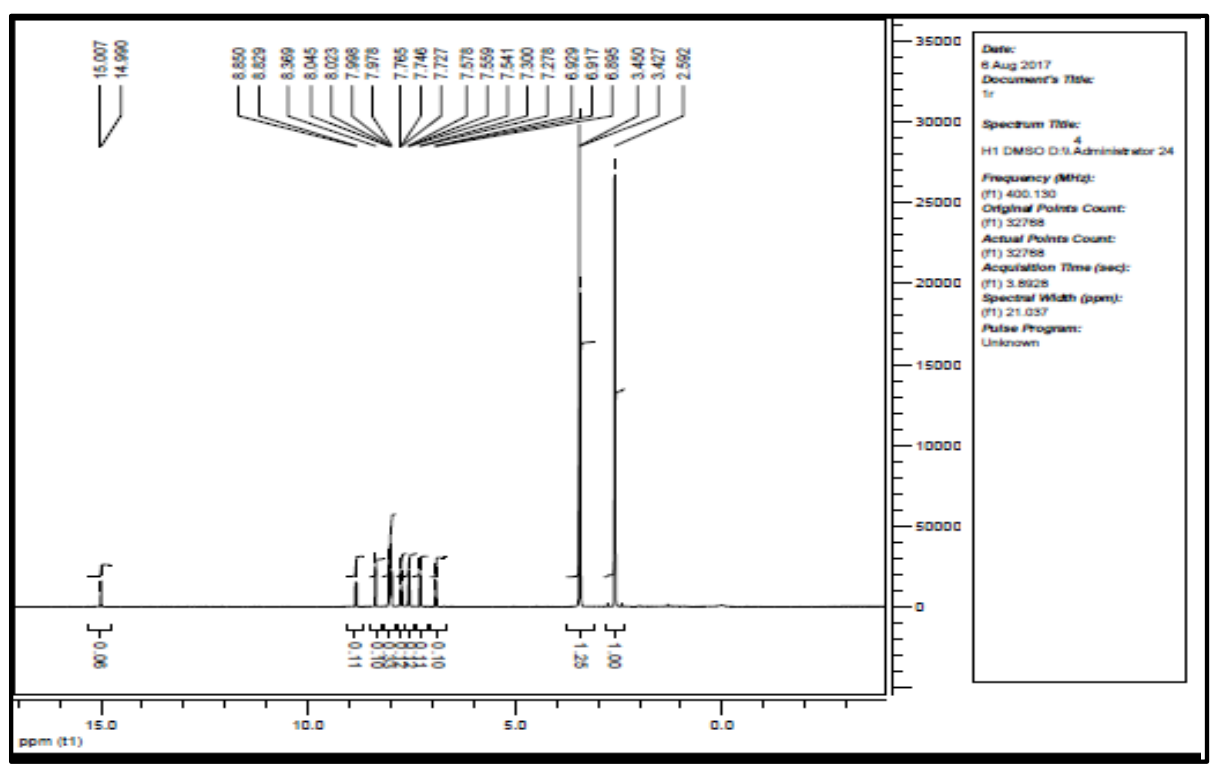

Fig.(11): ${ }^{1} \mathrm{H}-\mathrm{NMR}$ spectra of azo ligand

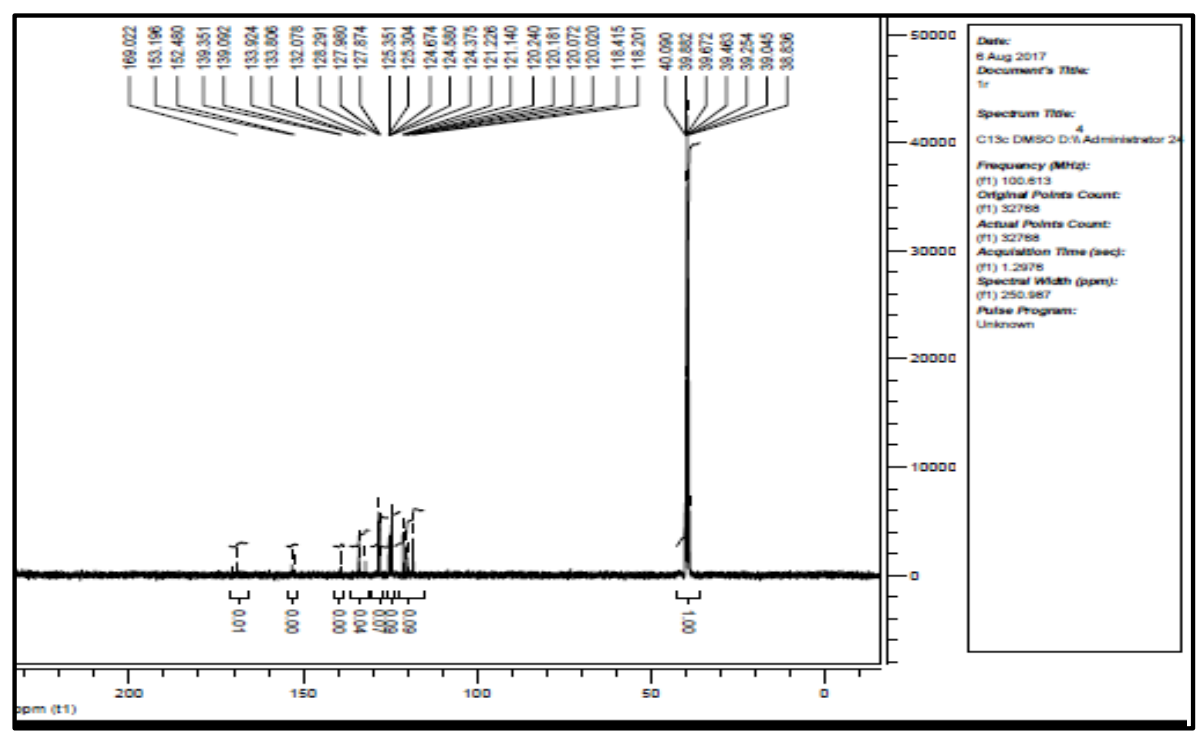

Fig.(12): ${ }^{13} \mathrm{C}-\mathrm{NMR}$ spectra of azo ligand

\section{4-Conductivity measurements:}

The complexes are non-electrolytes as shown by their conductivity in DMF at temperature The values are in the range $\mathrm{S}$ room $\mathrm{mol}^{-1} \mathrm{~cm}^{2}$.(Table 2)

According to these results the structural formula of prepared complexes may be proposed in Fig.(13 and 14). 


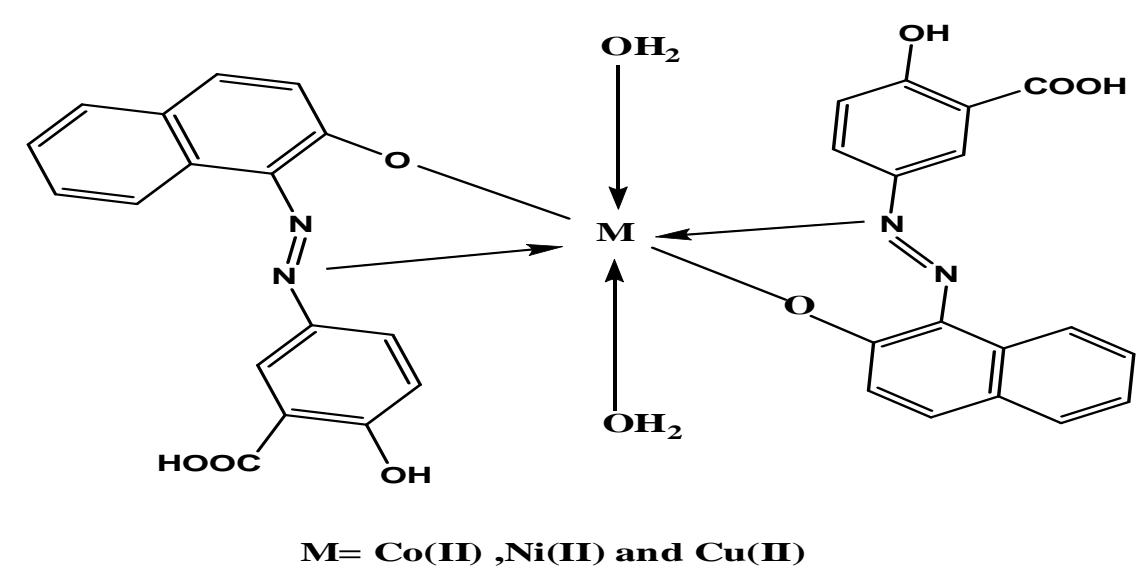

Fig.(13): The proposed structural formula of $\mathrm{Co}(\mathrm{II}), \mathrm{Ni}(\mathrm{II})$ and $\mathrm{Cu}(\mathrm{II})$

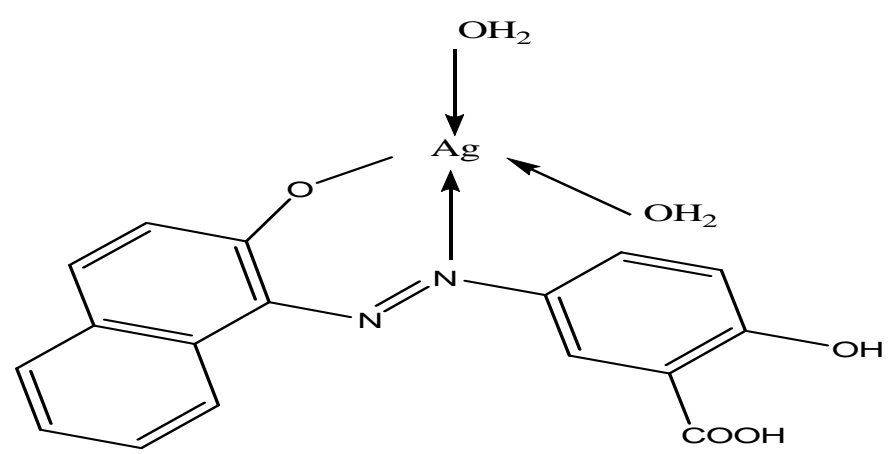

Fig.(14): The proposed structural formula of $\mathrm{Ag}(\mathrm{I})$

\section{REFRENCES:-}

1- R.Kılınc ,H. Kocaokutgen and E. Erdem,2006, Synthesis and spectral characterization of some new azo dyes and their metal Complexes, Transition Metal Chemistry,3 2:102-106

2- H. S. A Majeed, A.Y. Al-Ahmad and K. A.Hussain, 2011, The Preparation, Characterization and the Study of the Linear OpticalProperties of a New Azo Compound, Journal of Basrah Researches, 37:64-73

3- J.O.otuto and E.Osabohien ,2013,Synthesis and Absorption Spectra of Monoazo Dyes derived from 2-Methoxy-5-Nitro aniline ,Asian J. OF M. Science, 5:1-8.

4- H.D.Hanoon,2009, Synthesis Spectral and Antibacterial study of azo compound derived from (33'-Dimethyl -biphenyl -4,4'-diamine)and its metal complexes, National Journal of Chemistry,36,793803.

5- A. A.M.Ali ,2007,Synthesis and Characterization of the ligand 2-[(6-Nitro-2-benzo thiazolyl)azo]4,6-dimethylphenol and its complexes with $\mathrm{Fe}(\mathrm{II}), \mathrm{Co}(\mathrm{II}), \mathrm{Ni}(\mathrm{II}), \mathrm{Cu}(\mathrm{II}), \mathrm{Zn}(\mathrm{II}), \mathrm{Cd}(\mathrm{II}), \mathrm{Pd}(\mathrm{II})$ and $\mathrm{Ag}(\mathrm{I})$ Ions, National Journal of Chemistry,28,676-686.

6- S. M. Lateef , H.K.AL-Hakiem and N. A. Basim ,2016, Synthesis and characterization of new azo dye ligand derived from 4,4'-sulfonyl dianiline and 4-methy imidazole and its binuclear complexes with $\mathrm{Ni}(\mathrm{II}), \mathrm{Pd}(\mathrm{II}), \mathrm{Ag}(\mathrm{I})$ and $\mathrm{Au}(\mathrm{III})$,Der Pharma Chemica, 8,174-184.

7- R.Price,1970,The Chemistry of Metal Complex Dyestuffs from The Chemistry of Synthetic Dyes ,K.Venkataraman ED.Academic press. Vol.III.

8- N.M. Al-Jamali,2001,Solvent Extraction of Group (IIb) Metal Ion By New Organic Reagent 2[(chloro-2-benzenthiazolyl azo)]-4-methoxy phenol.M.SC.Thesis,University of Kufa. 
9- A.Muhi,2011 ,Spectrophotometric determination of micro amount of palladium(II) ,platinum(II) by using pyrazolone azo resorcinol, Baghdad Science Journal ,8:996-1004.

10- Sutton,D.,1968, electronic Spectra of Transition metal complexes ,Mc Graw-Hill publishing Compony lited . pp89.

11- H. H. Mohammed, Z.N. Mageed, M. Najim ,2013, Synthesis and biological activity study of 1[4, 5, 6, 7-tetrahydro-1, 3-benzothiazol-(2-yldiazenyl)]-2-naphthol Complexes , American Journal of Applied Chemistry, 1:92-99.

12- Nakamoto ,k. , 1997, Infrared of Inorganic and coordination Compouns .6 $6^{\text {th }}$, john- Wiely Inc ,New York , London,pp245.

13- K.R. Raghavendra, K. A. Kumar ,2013 , Synthesis Of Some Novel Azo Dyes And Their Dyeing, Redox And Antifungal Properties, International Journal of ChemTech Research , 5:17561760.

14- I. N.Witwit and H.A.mohamad ,2016, Synthesis and Spectral Study of new tetradentate azoazomethine ligand as a derivate of 4,5-diphenyl imidazole and its complexes with some of metal ions , principal education J.,22:1-12.

15- M.M.Al-Rufaee and H.M.Abede ,2008, Synthesis and Characterization of Metal of $\mathrm{Cu}$ (II) and Co(II) With Tetradentate Schiff bases, J.AI-Qadisiya for pure science ,13:370-376.

16- A. Abbas, R. S. Kadhim , 2016, Preparation, Spectral and Biological Studies of Azo Ligand Derived from Proline with $\mathrm{Cu}(\mathrm{II}), \mathrm{Ag}(\mathrm{I})$ and $\mathrm{Au}(\mathrm{III})$ Metal Ion , IOSR Journal of Applied Chemistry ,8:20-31.

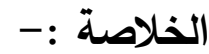

تضمن البحث تحضير ليكاند آزو جديد مشتق من المركب العضوي 2- نفثول وتحضير معقدات كيليتية جديدة للايونات

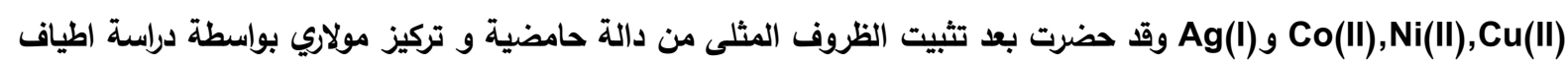

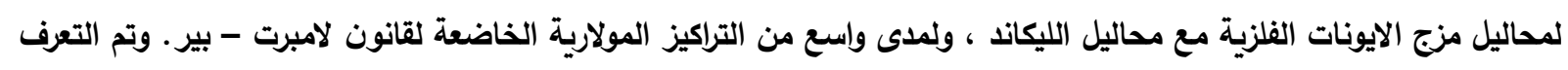

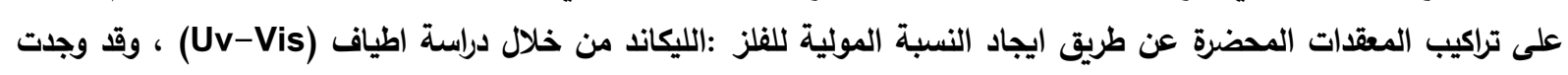

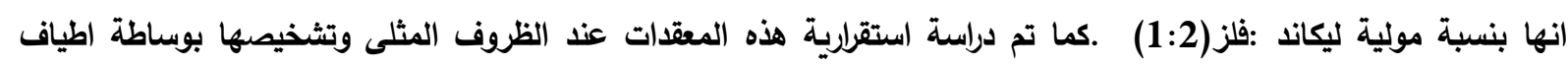
Uv.Visible,FT.IR, ${ }^{1}$ H.NMR, ${ }^{13}$ C-NMR 